\title{
Assessing Creative Writing in a Postmodern Era ${ }^{1}$
}

\author{
Yves Renaud \\ Haute école pédagogique du canton de Vaud, Lausanne, Switzerland
}

\begin{abstract}
How to teach creative writing at school? If the procedures inherited from writing workshops have undoubtedly proved efficient as regards text production, it is also clear that in Switzerland, as elsewhere in Europe and in the Anglo-Saxon world, the present use of evaluation grids with their numerous items prevents secondary school pupils from adopting the stance of an author. Why? Simply because the most innovative and "literary" texts are always surprising: They are "different”, and could not possibly result from writing guidelines devised only to facilitate a mechanical evaluation itself conceived for the sake of some illusory objectivity... Now, in our postmodern age with its rejection of models, what is more difficult than assessing the quality of creative writing? In our approach, we suggest restoring confidence in the teacher, an expert reader if any, who, acting as a publisher, dramaturge, or mere aesthete, knows how to take his pupils' texts seriously, acknowledge their aesthetic value, and look at apparent clumsiness as a possible promise of innovation. The teaching of creative writing lies both in this specific reception of budding works and in the teacher's performative utterances that, then and there, make the pupil a writer.
\end{abstract}

Keywords: creative writing, assessing artistic work, didactics, teaching French, highschool

\section{Introduction}

The reflection I put forward here is the first answer to a general question I ask myself and that I ask the didactics of writing, in particular in teaching French as a first language. It goes as follows: Can we make room for creative writing at school? This question goes hand in hand with a second: What are the conditions that enable teaching creative writing?

If our aim is to teach learners to master their language, it seems legitimate not to exclude the gratuitous, poetic dimension by limiting ourselves to teaching only functional, helpful writing that has no value outside its pragmatic perspective and the social obligations that motivate its use. Not to embark pupils on the exploration of creative highways and byways and the discovery of their own artistic abilities might be seen as a betrayal of pupils and their human dignity. Human beings are potentially poets, and school, I am convinced, must be a locus of initiation for the poetic.

The notion of teaching creativity is seemingly contradictory. How can you prescribe that which, by definition, strays beyond norms? How can you provide the landmarks and keys to understanding, not to mention ways of working, to pupils when they are expected to create original work as an "author", free of all preconceived models.

That we are in the throes of postmodernity renders the problem all the thornier. As Lyotard (1979) pointed out, we live in a time when the authority of moral and aesthetic models has been undermined. We have reached

Yves Renaud, Lecturer, Haute école pédagogique Vaud.

${ }^{1}$ Translation: Alan McCluskey. 
the end of the so-called grand narratives: Enough of your stories, we distrust normative shackles like the guardians of any temple. In this context, how can a teacher declare what is proper, correct, fair, or adequate? We even tolerate that spelling is no longer the priority of academic requirements.

How then can we judge the quality of a pupil's would-be literary work without defeating the aim: the emergence of innovation?

For a while, I believed that any research on the possibility of teaching literary creation should focus on the ways and means of writing and a set of instructions for pupils. Then I realized that such an approach missed the point. In fact, procedures to get pupils to write texts are now known. The anguish of the blank page is no longer on the agenda. Inspired by such things as writing workshops (Lafont Terranova, 2009) and the creative thinking of specialists in didactics like Bucheton $(1997,1998)$ or Tauveron and Sève (2005), they no longer constitute, in my opinion, a major problem in the didactics of writing. The path is traced out. We can always go further, of course, but now "we know how", and have done so for at least thirty years.

If we are to teach creative writing satisfactorily, we need to reflect on ways of assessing artistic work and propose new approaches to the question. Such is my aim here, or at least to indicate the way. As yet, I have not carried out the experimental and systematic verification that a full scientific approach would require. However, my data collection, as part of research on literary writing in high school, has led me to rethink current assessment procedures. I say “assessment”, but “reception” might be a better term. You will understand then why I do not provide charts and graphs in what follows, but rather reflections and proposals.

\section{The Experience of Odysseus: When School Evaluation Proves Ineffective}

My starting point was a corpus of more than six hundred texts written in two high school classes during fortnightly creative writing workshops. The aim was to see what would emerge from the regular and intense practice of creative writing, ultimately destined to produce literary productions. As mentioned above, the issue that gradually emerged was the analysis of written productions. This in turn raised the question of evaluation, where texts are considered not so much in terms of mastery of syntax and spelling, but rather literary potential and aesthetic quality. What evaluation grid should be applied? Here, current school practices proved to be inadequate.

To illustrate my point, let's compare two texts written by 17 year-old high school girls from the gymnasium in Morges (Canton of Vaud, Switzerland). As part of a study of the figure of Odysseus from Homer to today, students were invited to wander alone about the town of Lausanne, one January morning. In the afternoon they were asked to write an urban Odyssey beginning with the words borrowed from Homer's Odyssey (2004): "I am Odysseus, son of Laertes”.

Let's begin with Chloé's text ${ }^{2}$.

I am Odysseus, son of Laertes, and I am going to tell you the story of my journey across the seas. First, you must know that I set out from a tavern named "the Continental". I did indeed leave, but without knowing where I was going. Obviously, I had to decide my first direction, which then took over. I sailed a lot, following byways, wherever the wind decided. My goal was assuredly to return to Ithaca the Bavarian. But to do so, I do not know what prevented me, somehow I had to go via all imaginable waterways ... I began by swimming upstream, then (driven by the breeze) I slipped in a very narrow passage, where there was no one; that scared me a little because, normally, there is always a boat in such small channels. Approximately 200m further on, I turned right into a wide avenue that immediately reminded me of my

${ }^{2}$ Note that the translations have attempted to keep as close to the style and form of the pupils' texts. 
childhood when I used to visit my grandmother who lived at the end of a long boulevard in one of those tall, beautiful, old houses. I do not know why all of a sudden I thought about it, but anyway, the feeling grew ever stronger as I moved forward. It must have been the color of the water that reminded me of the color of those old buildings. Suddenly, I saw a column indicating a port a kilometer away. I immediately thought of a funeral necropolis. The stones forming the tower were all gray and black with the passage of time. I passed the harbor and soon found myself alone for a moment, lost in the immensity of the wave. A good few minutes passed before I realized that many rocks lay to my right. Strangely enough, they were white; a white that is rarely seen, an ivory white slap in the middle of the sea. In addition, their shape (spiraling upwards) only reinforced the feeling of oddity that took hold of me. Suddenly I began to wonder if I was not going crazy and if it was only a figment of my imagination. Maybe. A few meters from these curious rocks, I saw something smooth and shiny appear reflecting the waves on the surface. What a world of strange things! I was beginning to wonder if I had not eaten something that made me hallucinate, like when my companions were victims of the Lotus Eaters. I thought so for long and intense minutes. Further away, algae were floating on the surface. They were similar to hair except for their color. This pulled me from my thoughts, and I saw a small village in the distance. From where I stood, I could only see the silhouettes of the houses, nothing more. There were many, small, large, wide, high, etc. But the center of the village struck me. A huge building stood in the middle of all the others, imposing and majestic at once. Then I saw another boat approaching. I understood that it was a merchant ship because its cargo was extremely colorful but also the multitude of objects it was carrying. A man was on board and he was dressed strangely. I doubt he was a Greek. Suddenly I saw a woman on board too and all of a sudden a young lady called her by name "Martine!” The latter turned and was surprised to see her. Surely they had just embarked and were meeting up again... I just heard her ask how her newborn son was and then the boat left. Ah, what we can imagine just from this exchange, this meeting. All they will to be able to tell each other during their journey? That reminds me, yesterday, arriving home, while I was going through the city, I saw something that made me smile. A man, who must have been about 22, was pushing a trolley containing a very young child. At his side, his first son stood when a man dressed entirely in old skins and scraps of fabric arrived. He looked like a man in the street. He greeted the other man and I realized that they were, in fact, longtime friends. They exchanged a few words and then went on their way, very happy to have seen each other. As he left, the man in the street called out, "See you soon Pascal!” He walked a little and despite myself I followed. That was how I got lost in your beautiful town. I had not imagined it so, but that was how I explored your town. That reminds me of the corner of an alley where I discovered the entrance to a small shop. I ventured in and got lost in a mass of cumbersome and useless objects. I left happy to realize that even in the smallest spaces it is easy to get lost. Then, in the distance, I heard the tinkling of a bell that a restless child had rung as it laughed.

Far from the merchant ship, the wind bore me to Calypso's, which was surrounded at that time by other nymphs. When I arrived, they were eating a banquet. There were many of them; too many to count. They were beautiful and wore beautiful, colorful clothes. It was noisy, they were discussing. Suddenly Calypso saw me and came over. There she began by asking if I wanted some bread. I replied that I did, then took a seat. I ended up spending a lot of time there, seven long and beautiful years. At my departure, a flock of birds accompanied me when I left for the first time after those seven years. It was a noble omen. In my head, I could still hear Calypso saying a few hours earlier, "But listen to me!” I feel sorry for her, even now. She sincerely loved me but I had promised to remain faithful to Penelope and find her.

So I set out to sea and arrived at your place after many adventures that were painful, to say the least, because I did not have a boat but rather a raft. During my wanderings, I think I must have been hallucinating quite a lot, because I saw passages under the sea, I saw wrought iron doors and antique trinkets, and I think I even spotted a corpse. So I arrived here, at your home, in your noble Phaeacia. I was somewhat disturbed by the softness of your sand on arriving and by the fact that your beach looks like a large rectangle of sand. Oddity of nature, you might say. I also appreciate that nature is very present in your town. Many trees and flowers, etc. are to be found here. So you have part of my story. Sure, it's not over, but I am going to have a brief break as you have offered me, $\mathrm{O}$ king Alcinous, to feed and lodge me.

Chloe is clearly a "good" pupil. She has handed in a fair-sized composition without much difficulty. Her vocabulary is rich, she has mastered the rules of syntax and tenses and, like a good pupil, she alludes to Homer's poem, following the same narrative scheme. So, all is well. As teachers, we could point to the misuse of capital letters and there's an abbreviation to be removed, not to mention an anacoluthon to review. Such 
would be a classic approach to assessing writing. Note that the word "Breeze" should not have a capital letter and that, given the style of the whole, it would be more appropriate to write " $200 \mathrm{~m}$ " out in full. The control of the sequence of tenses is a real pleasure as is the use of the subjunctive tense that correct French requires in a phrase like "A good few minutes passed before I realized that many rocks lay to my right”. But there is the awkward construction and the repetition contained in the following: "I understood that it was a merchant ship because the cargo it was carrying was extremely colorful but also the multitude of objects it was carrying”. With the aid of a normative grid, we can only express the institution's satisfaction at bringing this pupil to clearly relate fictional events inspired by a walk and stimulating reading.

But the same set of instructions produce a wide variety of texts, as in the following example from Julie, which is much shorter (76 words compared with the 1,182 of Chloé).

I am Odysseus, son of Laertes.

I am here, before them.

Blond, blue, stiff, old, pink, curly, hesitant, fragile, hurried, musical, muddled, bald, helmeted, curious, cute, gentleman, small, passionate, wounded, different, smoker, with glasses, enamored, rich, happy, innocent, safe, sisters, heels, toilet brush, tolerant, flashy, alone, tourist, observer.

All have walked in front of me. Some laughing, others kissing. A few have looked up, smiled slightly. None recognized me.

And yet, if they had known...

How should we assess her text? How can we best approach it? It eludes traditional academic expectations. It is different. Should we judge it as worse than the previous text because it is shorter, lacks the simple past, doesn't respect the rules on the agreement of adjectives and only partially follows the narrative scheme? Its discourse is effective, all the same. You could say it is more interesting than Chloe's more conventional offering. If the instructions had fixed a minimum number of words or whatever other constraints, we would never have been confronted by these disturbing lines, which, although not devoid of interpretative difficulties, make sense to anyone who is willing to take them seriously. They even solicit analysis and commentary as well as scholarly and literary criticism. Julie, by following her Odysseus via a list of surrealistic epithets, has reactivated (perhaps unwittingly) one of the characteristics of Homer's Odysseus, well known for his countless qualifiers. What is the meaning of this abundance of words? We are unsure if they qualify Odysseus or the beings and objects that passed before him. Could it be that the hero is transformed by these encounters? What does this effect teach us about the possible understanding of the character? We sense Odysseus both polytropic and protean as in ancient tradition. This example illustrates how evaluation grids for creative writing as encountered in schools today are ineffective.

\section{The Inappropriateness of Evaluation Grids in Schools}

Indeed, today, the assessment of "creative" writing carried out in schools employs incredibly complex grids, preventing any consideration of those other texts that truly have to do with literature. People claim to teach writing and to check knowledge learnt, but at the expense of any creation, any "authorship” ... Not only do writing guides, accompanied by guides for appreciating what has been written, leave no chance to the autonomy of the would-be author, but they suggest that literature is the result of heartbreakingly obsolescent recipes: the variety of vocabulary, the absence of repetitions, a naive coherence, and portraits made up of at least three adjectives, for example. See the evaluation grids to be found in the Cantonal Reference Tests in 
compulsory education in the Canton of Vaud. ${ }^{3}$ Such an approach is based on a flagrant ignorance of poetic writing in general and ignores all contemporary literary writing. Bucheton (1997) already pointed out: "Texts obeying all the formal criteria and all the social and generic criteria can be devoid of interest and empty” (p. 253).

How did this happen? These grids are the product of an education based on competence benchmarks that we saw fit to adopt in the name of fairness. We had read Bourdieu and Passeron (1964) and their critical observations about "Heirs": Selection on the basis of cultural criteria could only favor the privileged social classes who benefited from a cultural heritage acquired within their family. It was decided to stick to technical and objective skills to the detriment of knowledge, and thus ensure greater social justice in the academic race. The drawback: cutting up human skills into ever finer, more precise units, resulted in us loosing sight of humans and their genius, their freedom. Worse, we wanted to strive for greater equality and greater democracy in society, instead we hindered the emergence of any creation in favor of the "innovativeness" of employees who are competent but ignorant, ready to accommodate the requirements of a liberal society and willingly available for work.

Not that I am suggesting we give up active methods. On the contrary, it is time to remember that alongside this standardized pragmatism there is a wild pragmatism, as epitomized by the active pedagogy of thinkers like John Dewey, Freinet, or Olivier Decroly (Vergnioux, 2009); a pragmatism that grants the pupil his or her freedom as a writer.

As I said, we have had to find ways and means to ensure that pupils dare write and are not blocked by a representation of writing inculcated by school, so they can adopt the stance of an author. We are aware of the work of Barré-De Miniac (2000) on the subject. We also know of that of Tauveron and Sève (2005) on the development of an artistic relationship: Their theories are amongst the best I have read on the subject. But don't we need to go even further, confronted as we are by pupils' texts that challenge any possibility of an understanding between the reader and the author and throw off balance even the most open of attitudes of the reader? If we are to encourage the creation of works of art, the risk may be worth it, especially if it is to be anchored in our time. According to Frank Pavloff (2007), writer and editor, “contemporary literature comes with its predicaments, its immediacy, with its aside, hello, I exist, but tomorrow perhaps I will no longer be here, so I hasten to tell you what I have at the end of my pen”. That's what makes it special. "Contemporaneity is an attempt to recreate the emotions and the tension in the world, [...] by means of writing that itself is under pressure” (pp. 97-98). The urgency and immediacy of contemporary writing can therefore be scary for school, an institution that is the symbol of a certain continuity only to be achieved with the assurance of time.

\section{David's Strange Text}

What should we do, for example, with this text of David, a 17 year-old student in a business school?

We thought we knew his sense of humor, seated on this chair, his hair gray, showing early signs of hair loss. Hair that men and women fell in love with. Always wearing glasses, that earlier, no one knew he used to thwart, to thwart whom? To thwart what? And him wearing this black shirt, who could have known his thoughts? We knew of the tragedy that befell him, losing his other half, his love, his love was weary, from then on, we no longer knew where or what could happen the next day. Village gossip said we galloped together, yet we never looked into each others' eyes, as we saw, with

\footnotetext{
${ }^{3}$ Examples can be found (in French) on the website of the Canton of Vaud at the following url: http://www.vd.ch/themes/formation/scolarite-obligatoire/evaluation/ecr/.
} 
the awkward look of someone about to kill, spitting at you what should not have come out. We tore each other's clothes off. Yet no pleasure came from us. Perhaps we should never have removed his lover, perhaps, had we changed our visions of horror? Caught up we moved off. We had each fired all the bullets from our arm, his half looked like an inert monkey. Yet more tenacious, more horrible, his razor tried to cut me in two. The blade we had bought together. One thing was sure; one of us would die.

This is a text of a quite different nature, stranger than Julie's about Odysseus, son of Laertes. It follows a morning of observation made about town for a writing activity. David had watched a man wearing a black shirt, sitting on a chair somewhere in town. He then had to imagine the existence of that person and write a story, in the form of an evocation of one or two pages (like the fragments of people’s lives by Régis Jauffret, 2001).

I wanted to see how high school teachers would react, so I showed a dozen of them David's work and asked them to annotate it as they would the work of one of their students. Here, briefly, are my findings:

Some were tempted to reject the text. Several wrote, "It is not comprehensible" or even, "I do not understand". Some questioned the author's intentions: Are these inconsistencies intentional? Were the sentences deliberately complicated, one asked. Another said the reader got lost trying to figure out the logic of the pronouns, in particular the use of "we" throughout. All but one pointed to spelling mistakes or supposed punctuation errors, as any good teacher would. Some even fixed expressions that were not incorrect but judged inelegant. Guidance was given about how to rewrite the text without any consideration for the rhythm of the sentences. In short, the comments remain anchored in a criteria-based grid, referring solely to a standardized use of language, paying no attention to the possible innovativeness of the text.

Alongside these remarks there are those that are more open, amazed even, and sometimes very subtle. One talks of a "beautiful initial description", even though the first sentence is an anacoluthon that others deem an error ("This sentence does not make sense") or at least elliptical. Then there is the praise: "finesse", "sensibility", "a flare for writing", and "a brainwave". The author is credited with what the expert reader perceives in it: "traces of Rimbaud" are pointed to, or, more simply, a "concerted drive to create a relatively short portrait". The end of the story is particularly praised. Then there are those who single out particularly successful aspects such as an "excellent cock-and-bull story" or an "excellent pun". One of these teacher-readers mentions the lexical fields (dark, dramatic, gossip, and morbidity). Another brings up the word "die" that ends the piece, seeing it as a welcome echo of the "humor" that opens the text, and, as such, reveals a real progression, a dramatic tension.

Finally, whatever the remarks are, they are often formulated as questions. The teachers give voice to their confusion, but also their willingness to dialogue with a pupil who is promoted to the rank of author. "For me your text says this... or raises this or that problem, what do you think?" "Does it disturb you that the reader reacts like this?” Their approach is similar to that of publishers with their authors. As Daireaux and Pacaud (2013) write, "the editor performs essential functions for the author. (...) He receives a text and detects a talent in the material, a voice he wants to hear" (p. 174). It is not surprising to see the teacher seeking to identify and develop the "talent" of his pupils; did not Plato call his master a midwife of souls (particularly in Theaetetus, 1950, p. 95)? Bruner refreshes this idea in his definition of a teacher as a "guardian who engages a child in a task and accompanies its realization" (1998, p. 277). Raising the question of how to become a writer, Daireaux and Pacaud explain that "the click sometimes stems from encouragement and an invitation to continue a draft" (2013, p. 167). The teacher therefore has everything to gain from commenting a pupil's text as a publisher would text, rather than correct them. 


\section{Open Evaluation and Its Perlocutionary Action}

It is when the teacher, as an expert reader if ever there was one, takes the pupil's lines seriously and sets aside his position of corrector-censor and marvels at the text, naming what makes sense to him and asking the author about it, that, in my opinion, is when the teaching of creative writing begins. Teaching is then a question of how the text is received, not in a prior recipe or a writing guide. The teacher thus dubs the pupil: "Yes, you are a writer, and I read you as such". We should not underestimate the performative dimension of these words, as mentioned by Austin (1991) in his theory of speech acts, specifically the perlocutionary ${ }^{4}$ action of enunciation. No need to strive further to develop the posture of a writer, given as a poor substitute for that of the author, suffice it to read pupils' productions as one reads a text of a writer who is already recognized as such (i.e., published) to transform the pupil into a poet, even if only ephemerally so. It is up to him to persevere, to assert his style, to work on his own voice. He knows that the written word is meant to be read and taken seriously by readers who are often benevolent and curious, ready to adopt a position as a reader that can be quite unexpected.

I have observed this phenomenon in writing workshops led by Mathieu Bertholet, actor, director, and playwright. When a text was shown to him, he said, pointing to a particular formulation or an aspect of the text, "That makes sense to me", even though the author did not necessarily mean it so. The latter then adopts an attitude that I would call that of an author-expert: At first, he tries to deny such and such an interpretation and apologizes for having left a comma where you would not expect one, then he resumes, wondering what the text, as it stands, could mean or could be worth, and whether it corresponds to something he would like to adopt, affirm, or modify.

When I asked David about his text two years later, he in no way regretted his hermetic style or its awkwardness. He spoke of his intentions, his choices, his inspiration... That evening, he sent me an annotated version by email with his explanatory comments. I would not have imagined a pupil could attach so much importance to an exercise! What a mistake... The consideration paid to his text had set him up as an author.

\section{Conclusion}

This experience (and similar ones) should encourage us to review the way we apprehend (if not evaluate) those pupils' texts with literary pretensions. First, let us see what resonates with us, what makes sense. Let us explore possible interpretations, like contemporary playwrights, adopting an attitude of understanding, interpretation and benevolence in our questioning, not because we are focused on correction, but rather on accepting a text that exists and appreciating it (and of course discussing it without necessarily considering possible improvements). Does David's text really need to be improved? Its strangeness and its rhythms are challenging. It is not so easy to correct or clarify the syntax without breaking the overall rhythm, a rhythm that is an integral part of the quality of the text. One of the professors to whom I submitted it, began by making a few typical academic remarks, before stopping abruptly and saying, annoyed: "Damn it, this text is strange, I find it beautiful and that is enough. I just want to listen to it”. And with that a space had opened up for creative writing at school.

\footnotetext{
${ }^{4}$ Austin refers to a perlocutionary act as follows, "Saying something will often, or even normally, produce certain consequential effects upon the feelings, thoughts, or actions of the audience, or of the speaker, or of other persons: and it may be done with the design, intention, or purpose of producing them”, from J. L. Austin (1962), How to Do Things with Words, p. 101.
} 


\section{References}

Austin, J. L. (1991). Quand dire, c'est faire (How to do things with words). Paris: Seuil.

Barré-De Miniac, C. (2000). Le Rapport à l'écriture. Aspects théoriques et didactiques (The relationship to writing. Theoretical and didactical aspects). Villeneuve d’Ascq: Presses universitaires du Septentrion.

Bourdieu, M., \& Passeron, J. C. (1964). Les Héritiers: les étudiants et la culture (The heirs: Students and culture). Paris: Minuit.

Bruner, J. (1998). Le développement de l'enfant: savoir faire, savoir dire (The development of children: Knowing how to do and to say). Paris: Presses Universitaires de France.

Bucheton, D. (1997). Conduites d'écriture au collège et au lycée professionnel (Supervising writing in colleges and vocational schools). Marly-le-Roi: CRDP de l'Académie de Versailles.

Bucheton, D. (1998). Ecrire c’est toujours dire je (Writing always means saying “I”). Cahiers pédagogiques, 363, 53-55.

Daireaux, S., \& Pacaud, A. (2013). L'écrivain à sa table de travail. Être romancier aujourd’hui (The writer at his worktable. Being a novelist today). In Nouvelles formes du récit. Parcours dans la littérature contemporaine (New forms of narrative. Paths through contemporary literature). Paris: Gallimard.

Homère. (2004). L'Odyssée (The Odyssey). (P. Jaccottet, Trans.). Paris: La Découverte.

Jauffret, R. (2001). Fragments de la vie des gens (Fragments of people’s lives). Paris: Gallimard.

Lafont-Terranova, J. (2009). Se construire, à l'école, commesujet-écrivant: l'apport des ateliers d'écriture (Self-construction at school through writing: The contribution of writing workshops). Namur: Presses universitaires de Namur-CEDOCEF Diptyque 15.

Lyotard, J. F. (1979). La Condition postmoderne (The postmodern condition). Paris: Minuit.

Pavloff, F. (2007). Quelle littérature contemporaine proposer à l'école, selon quelles modalités ? (What contemporary literature should one propose at school and in what form?). In J. L. Bayard and A. M. Mercier-Faivre (Dir.), Vous avez dit contemporain? Enseigner les écritures d'aujourd'hui (You said contemporary? Teaching today's writings). Saint-Etienne: Presses universitaires de Saint-Etienne.

Platon. (1950). Théétète (R. Léon, Trans.). In Euvres complètes II (Complete Works II) (pp. 83-192). Paris: Gallimard.

Tauveron, C., \& Sève, P. (2005). Vers une écriture littéraire ou comment construire une posture d'auteur à l'école de la GS au $C M$ (Striving for literary writing or how to develop the stance of author at primary school). Paris: Hatier.

Vergnioux, A. (2009). Théories pédagogiques, recherches épistémologiques (Pedagogical theories, epistemological research). Paris: Vrin. 